\title{
The Role of Local Government and Illegal Foreign Refugees
}

\author{
Fitrisia Munir \\ Islamic University of Riau \\ Pekanbaru, Indonesia \\ Student of Doctoral Program at Padjadjaran University \\ mfitrisia@yahoo.com
}

\begin{abstract}
Indonesia is one of the destination countries for illegal foreign refugees every year, in the history of a small proportion of Indonesia's population has joined the illegal foreign refugees from various countries so that they get the recognition of citizens. Indonesia is located in a strategic position because it is on trade and cruise lines international. Indonesia became the place a stopover for traders, exporters, importers, and intermediaries the trade from abroad will conducting economic activities on the Continent Asia to the Australian Continent or otherwise. UNHCR stands under the auspices of the United Nations (UN) formed by the UN general assembly in 1950 and has responsibility for provide international protection for refugees and find solutions settlement of refugee problems (UNHCR, 2007). Job and function The UNHCR in Indonesia is providing refugee and seeker status asylum for immigrants who do not yet have status, organize and assist the process the placement of immigrants to the destination country if the immigrant has a status as a refugee, the latter is helping to process voluntary repatriation immigrants who can't get refugee status. L ocal government policy has been indirectly involved in dealing with the issue of illegal foreign refugees, among the unpreparedness of facilitating housing and other accommodation. So there are some illegal foreign refugees living in immigration offices for a long time and in less desirable places. This issue becomes a psychological and social burden on the environment of the communities in which they live.
\end{abstract}

Keywords- Local Government, Illegal foreign refugees, Constitution of Immigrant, UNHCR

\section{INTRODUCTION}

Some countries in Asia are a country that is a share of legally and illegally foreign refugees, because the location and geographical conditions make it possible. Indonesia has a strategic geographic position for sea transportation routes, located between two continents (Asian Continent and Australian Continent) and two oceans (Indian Ocean and Pacific Ocean). The Convention defines refugees is as persons fear persecuted for reasons of race, religion, citizenship, certain social group membership, or political opinion, is outside of its nationality, and can't do so or, because such fears, protection of the country. Indeed, the challenge of understanding the movements of refugees is huge, global, and as a society but we are confronted with it on a daily. Yet, in terms of simulation, the challenge appears to have been largely ignored.

Director General of Regional Autonomy Ministry of Home Affairs Indonesia said foreign refugees scattered in several areas in the country remain the responsibility of international organizations of the United Nations, in particular the UN sub organization of refugee and immigration (UNHCR), and the central government. Some countries open their borders, and attempt to set up adequate facilities, whereas other countries close their borders, in an attempt to redirect the refugees. According to him, the local government is not authorized to take care of foreign refugees unless mandated by the central government after coordinating with UNHCR. Foreign refugees are not local government affairs, but UNHCR. He asserted the entry of foreign refugees illegally and legally to a country should be known to the UNHCR and coordinate with the Ministry of Foreign Affairs to then notify the local government. Data collection and shelter became the responsibility of UNHCR assisted by the Ministry of Foreign Affairs. People flee their homeland for very good reasons. Yet the macroscopic phenomenon of large influxes of refugees severely concerns both governments and members of the public.

\section{CASE STUDY : INDONESIA}

Based on UNHCR data, the immigrants or refugees who come Indonesia there are 14,425 people, data as of January 31, 2017. Consists of 8,039 refugees and 6,386 asylum seekers, this is important. The refugees then spread to all parts of Indonesia. A total of 2,177 people are at immigration detention houses (rudenim), 2,030 people in Immigration office (kanim), 4,225 people in community house, and 5,993 are independent immigrants. The independent immigrant are difficult to record, they can move around and this can be a problem. In the Peak, Bogor, there are 2,500 immigrants. The Bogor Regent has requested our assistance, feared there will be influence to the local people and the crime. The number of rudiment in Indonesia is not proportional to the number of refugees who enter. It then creates a new problem. In Indonesia there are 13 rudenim, of which 2,177 are scattered to rudenim, but only 1 rudenim are of sufficient capacity, in Jayapura, 
but the rudiment of Jayapura is reluctant to accept refugees from other rudenim cities.

Some of the problems arise when these illegal foreign refugees enter the local area in Indonesia most refugees come to Indonesia via Malaysia. While developed countries typically accept refugees in a planned manner with predetermined numbers, developing countries accept refugees in ad hoc manner with no prior plans. Moreover, the impact of refugees on the host country's economy is determined to some extent by its stage and rate of economic development (Sesay, 2004). The United Nations High Commissioner for Refugees' (UNHCR) estimates that in 2011there were 10.4 million refugees in the world with most refugees migrating to neighboring countries and only 17 percent of refugees leaving the geographical region (UNHCR, 2011).

War, violence and oppression are shown to be the fundamental reasons behind why refugees are created (Hatton and Williamson, 2004) and sincemost of the world's conflicts occur in less developed countries, refugee immigration tends to primarily affect their neighboring and, thus,similarly less developed countries (Sesay, 2004).Based on the regulations of the Director General of Immigration IMI- 1489.UM.08.05 Year 2010 on Immigrants Handling Illegal.

Indonesia also have no obligation and authority to take action international against refugees and asylum seekers entering Indonesia. Indonesia only deals with the immigrants given the action administrative by an immigration officer or carrying documents and already known by the immigration authorities. illegal foreign refugees come from several countries In its development, the arrival and whereabouts of foreigners initially as illegal immigrants who later declared themselves as seekers asylum seeker and refugees in Indonesian territory increasingly has had an impact in the fields of ideology, politics, economic, socio-cultural, national security, and immigration vulnerabilities. Indonesia does not recognize refugees asylum seekers because there is no provision to regulate it. So that when the refugees in the regions, local governments will not focus on taking care of it, but psychologically and socially cause inconvenience surrounding the community.

As of the end of March 2017, 6,191 registered asylum seekers in UNHCR Jakarta were cumulatively from Afghanistan (42\%) and Somalia (14\%). While some 8,279 refugees are registered in UNHCR Jakarta from Afghanistan (57\%), Myanmar (10\%), and Somalia (7\%). Refugee flows differ from standard migration in two ways: first, the flow of refugees is typically a simultaneous group movement of individuals escaping persecution in their home country versus a sequenced movement of economic immigrants who are individuals seeking better jobs and economic security (Cortes, 2004); and second, the flow of refugees tend to be predominantly from poor economies (Stark, 2004).

This article suggests that not all countries willing to accommodate foreign refugees are moreover illegal, until there is clarity that the state is fully responsible for their arrival. Some countries in Europe have made policies about these refugees, but in Indonesia can't because of different climate. This means the country of Indonesia is so vast that it can't control the refugees who come, besides economic factors also determine this policy will follow. Local and central governments work together when the influx of refugees has entered, the weakness is a lack of readiness. There is also no socialization and direction of the center to the region. This problem is very necessary to be completed because every year the number of refugees will be many, if there is no serious supervision then the more refugees will come. Local governments should adopt their own policies, as refugees come to the region, and the head of the region must act for the safety and comfort of the community.

\section{Discussion}

The explanation of the role of local government against these illegal foreign refugees should receive attention from the central government, as the possibility of these refugees is faster to come to the region than to the center. The reason is because of the ease of transportation and the adjacent areas. The policy of the local government against the central government on this issue cannot be restricted because the regional government understands the region and the issues that will be facing it. Restrictions and strict supervision of local governments must be supported by the central government, in order to maintain the unity of Indonesia. Some of these illegal foreign refugees enter Indonesia including syria, afganistan, myanmar, etc. their arrival brought with various problems. The local government can;t act on the international legal channels because there are several parts that we have to limit. Although authority exists in the local government because they come directly to our area. So that every policy of local government is essential to deal with illegal foreign refugees.

One of the refugee issues in asia of Myanmar includes Rakhine State (known as Arakan State before 1989), a borderland with Bangladesh to the north and the Bay of Bengal to the west (figure 1).The Rohingya people are a Muslim minority group residing in the Rakhine state, the Rohingya people are considered "stateless entities", as the Myanmar government has been refusing to recognize them as one of the ethnic groups of the country. For this reason, the Rohingya people lack legal protection from the Government of Myanmar, are regarded as mere refugees from Bangladesh, and face strong hostility in the countryoften described as one of the most persecuted people on earth. To escape the dire situation in Myanmar, the Rohingya try to illegally enter Southeast Asian states, 
begging for humanitarian support from potential host countries.

Figure 1 : Location of Rakhine State in Myanmar



\section{Flgure 1: Rakhire State in Myanmar}

Another case in the late 1970s the human boat crisis in Southeast Asia stems from a civil war between North Vietnam and South Vietnam which forced thousands of Vietnamese to leave their country for a better life. Indonesia accepts Vietnamese boatmen and places them on Galang Island, Riau Archipelago. this is due to the vast geographical conditions of Indonesia, not a few local governments managed to rescue foreign refugees who stranded in the area to the corner of the smallest island in Indonesia. however they become the views and responsibilities of local governments, due to humanitarian factors. The refugee crisis to date has begun to increase, as a severe wave of refugees takes place in Europe. this refugee flare becomes a long debate, so every country has a duty to be ready for the possibilities that will happen.

\section{Results}

One result of the political upheaval is the displacement of many of the few who become little foreign workers, but there are others who have been stranded for years because of political uncertainty. The nature of Indonesia's foreign policy is free and active. Free, meaning the state of Indonesia does not favor one of the power blocks in the world. Active means the state of Indonesia is always active in creating world peace. The State of Indonesia is active in solving international problems. Relationships woven by a country with other countries, of course, can not be separated from the inter-country manners. If in the association of humans in neighboring life there are so-called societal etiquette, then in the intercountry association there is the same thing. Each country has its own political policy. The political policy of each country in international association is called foreign policy.
In this context it can be concluded that the role of government in the regions and centers must be the same in addressing the problem of refugees, because our foundation has such foreign policy. Then the wave of refugees can't we reject or ignore, because the situation of the world community is growing and the refugees want to get the certainty of political rights and obligations for the sake of survival. UNHCR as an organization under UN supervision strongly believes that these refugees will continue to spread, this is caused by the inconsistency of the state to solve humanitarian problems.

\section{References}

[1] Cortes, K.E. ,2004. Are refugees different from economic immigrants? Some empirical evidence on the heterogeneity of immigrant groups in the United States.Review of Economics and Statistics 86(2), 465-480

[2] Derek Groen. 2016. Simulating Refugee Movements: where would you go? Volume 80, 2016, Pages 2251-2255, The International Conference on Computational Science

[3] Sesay, F.L., 2004. Conflicts and refugees in developing countries. Diss, lmu.

[4] Stark, O. (2004). On the economics of refugee flows Review of Development Economics 8(2):325-329.

[5] Sucharita Ghosh Ali Enami. 2015. Do Refugee-Immigrants Affect International Trade?Evidence from the World's Largest Refugee Case, Journal of Policy Modeling

[6] UNHCR Statistical Online Population Database, 2011.United Nations High Commissioner for Refugees (UNHCR). Data extracted: $02 / 02 / 2011$.

[7] Wikipedia.org/wiki/2015_Rohingya_refugee_crisis 